\title{
Analisis Risiko Dengan Metode ISO 31000 Pada Disperinnaker Kota Salatiga Bidang Industri
}

\author{
Andeka Rocky Tanamaah*1, Lela Dina Berliana ${ }^{2}$ \\ ${ }^{1,2}$ Sistem Informasi, Fakultas Teknologi Informasi, Universitas Kristen Satya Wacana \\ Jl. Blotongan, Sidorejo, Kota Salatiga, Jawa Tengah, Indonesia \\ e-mail: *1'tanamaah@ uksw.edu, ${ }^{2} 682017084 @$ student.uksw.edu
}

\begin{abstract}
Abstrak
Setiap instansi pemerintah, pasti memiliki aset administrasi dan sistem aplikasi yang digunakan, begitu juga dengan bidang industri Disperinnaker Kota Salatiga. Dari setiap aktivitas tersebut, pasti memiliki ancaman dan risiko. Untuk meminimalisirnya, diperlukan suatu analisis risiko agar dapat melakukan pencegahan, penangan, serta perbaikan terhadap risiko yang terjadi. Analisis risiko ini menggunakan metode ISO 31000. Metode ISO 31000 lebih perspektif dan konseptual dibandingkan dengan metode ISO lainnya. Terdapat 2 tahapan dalam analisis risiko ini, yaitu penilaian risiko dan perlakuan risiko. Tujuan dilakukan analisis risiko dengan metode ISO 31000 agar dapat mengidentifikasi kemungkinan risiko yang muncul serta mengetahui level dampak dari risiko tersebut dan memunculkan usulan tindakan atau upaya yang dilakukan untuk meminimalisir risiko yang terjadi, baik terhadap aset maupun aplikasi yang digunakan pada bidang industri Disperinnaker Kota Salatiga, sehingga aktivitas dapat berjalan secara optimal.
\end{abstract}

Kata kunci- Analisis Risiko, International Organization for Standardization (ISO) 31000, Bidang Industri

\begin{abstract}
Every government agency, must have administrative assets and application systems used, as well as the industrial sector of the Salatiga City Disperinnaker. From each of these activities, there must be threats and risks. To minimize it, a risk analysis is needed in order to prevent, treat, and improve the risks that occur. This risk analysis uses the ISO 31000 method. The ISO 31000 method is more perspective and conceptual compared to other ISO methods. There are 2 stages in this risk analysis, namely risk assessment and risk treatment. The purpose of conducting a risk analysis using the ISO 31000 method is to identify possible risks that arise and to know the level of impact of these risks and to come up with proposals for actions or efforts to minimize the risks that occur, both for assets and applications used in the Salatiga City Disperinnaker industry. so that activities can run optimally.
\end{abstract}

Keywords - Risk Analysis, International Organization for Standardization (ISO) 31000, Industrial sector

\section{PENDAHULUAN}

Dinas Perindustrian dan Tenaga Kerja (Disperinnaker) Kota Salatiga merupakan salah satu instansi pemerintah Kota Salatiga yang terletak di jalan Ki Penjawi No.12a, Sidorejo Lor, Kecamatan Sidorejo, Kota Salatiga, Provinsi Jawa Tengah. Disperinnaker Kota Salatiga terdiri 
dari dua (2) bidang yaitu bidang Industri dan bidang Tenaga Kerja. Bidang industri membahas tentang Usaha Kecil Menengah (UKM) dan Usaha Mikro Kecil dan Menengah (UMKM). Sedangkan bidang Tenaga Kerja membahas tentang urusan ketenagakerjaan, pelayanan pembuatan AK/1 (Kartu Kuning), rekomendasi paspor CPMI, tanda daftar BKK, validasi pembayaran DKPTKA, pencatatan peserta pemagangan, info lowongan kerja, penempatan transmigrasi, rekomendasi pendirian kantor cabang PPTKIS, dan pendaftaran pelatihan di BLK. Dalam setiap aktivitas, pasti muncul berbagai ancaman dan risiko yang mengganggu bahkan melumpuhkan aktivitas kinerja di dalamnya, termasuk penggunaan sistem, sehingga sistem tidak berjalan secara optimal. Maka, perlu dilakukan suatu analisis risiko terhadap kemungkinan ancaman dan risiko yang muncul agar dapat melakukan pencegahan, penanganan, serta perbaikan terhadap kemungkinan risiko yang terjadi. Karena dengan melakukan analisis risiko dapat membantu pengaturan risiko sistem dan teknologi informasi, membantu perkembangan proses bisnis dan memberikan keuntungan, dan dapat memanajemen sumber daya yang efektif. Dengan kata lain, analisis risiko adalah kegiatan penemuan dan analisis sistematis atas kerugian yang dihubungkan dengan tingkat keuntungan yang akan dicapai.

Bidang industri Disperinnaker Kota Salatiga dalam melakukan aktivitasnya, masih menemukan beberapa masalah yang mengganggu. Seperti kehilangan data, program crash, server down, hardware yang rusak, listrik padam, dan masih banyak lagi. Dari permasalahan diatas, maka perlu dilakukan analisis risiko dengan metode ISO 31000. Pentingnya melakukan analisis risiko pada setiap aset dan sistem yang dimiliki karena semua aktivitas yang ada di dalam perusahaan atau organisasi pasti memiliki risiko yang bisa saja muncul setiap saat tanpa bisa diprediksi sebelumnya [1]. Penelitian ini menggunakan metode ISO 31000 karena perspektif ISO 31000 yang lebih luas dan konseptual dibandingkan dengan metode ISO lainnya. Tujuannya, agar dapat mengidentifikasi kemungkinan risiko yang muncul serta mengetahui level dampak dari risiko tersebut dan memunculkan usulan tindakan atau upaya yang dilakukan untuk meminimalisir risiko yang terjadi, baik terhadap aset maupun aplikasi yang digunakan pada bidang industri Disperinnaker Kota Salatiga, sehingga aktivitas dapat berjalan secara optimal.

\section{METODE PENELITIAN}

\subsection{Analisis Risiko}

Risiko tentang sistem informasi menghasilkan banyak faktor dan komponen yang saling mempengaruhi [2]. Federal Standard mendefinisikan keamanan informasi sebagai perlindungan terhadap perbuatan yang tidak sah, transfer, modifikasi, atau perusakan baik disengaja ataupun tidak disengaja [3]. Sistem informasi merupakan salah satu bagian dari bidang industri Disperinnaker Kota Salatiga untuk mencapai tujuannya.Untuk menjaga sistem informasi yang efektif dan efisien bukan hal yang mudah, karena risiko tidak diketahui secara pasti kapan datangnya.

Dalam memanajemen risiko, setiap organisasi atau perusahaan harus memiliki jadwal khusus untuk menilai dan memitigasi risiko secara berkala dan harus fleksibel untuk memungkinkan perubahan jika diperlukan [4]. Setiap proses manajemen risiko terhadap ancaman dan risiko serta hasil dan pengaruhnya, dapat diterapkan dalam tahapan analisis risiko sebagai hasil analisa dan sebagai bahan evaluasi [5]. Analisis risiko adalah sebuah teknik untuk mengidentifikasi dan menilai faktor kemungkinan risiko yang mengganggu aktivitas pada bidang industri Disperinnaker Kota Salatiga serta memberikan usulan pengendalian yang tepat sesuai dengan kemungkinan risiko yang terjadi. Dengan begitu bidang industri Disperinnaker Kota Salatiga perlu melakukan analisis rasio untuk menyelamatkan dari kerugian yang disebabkan oleh munculnya peristiwa yang tidak diinginkan yang memiliki risiko dan ancaman

Andeka, et., al [Analisis Risiko Dengan Metode ISO 31000 Pada Disperinnaker Kota Salatiga Bidang Industri] 
bagi tujuan [6][7]. Ada beberapa tahapan dalam menganalisis risiko, yaitu perencanaan, identifikasi risiko, penanganan, dan monitoring. Dapat dilihat pada gambar 1.

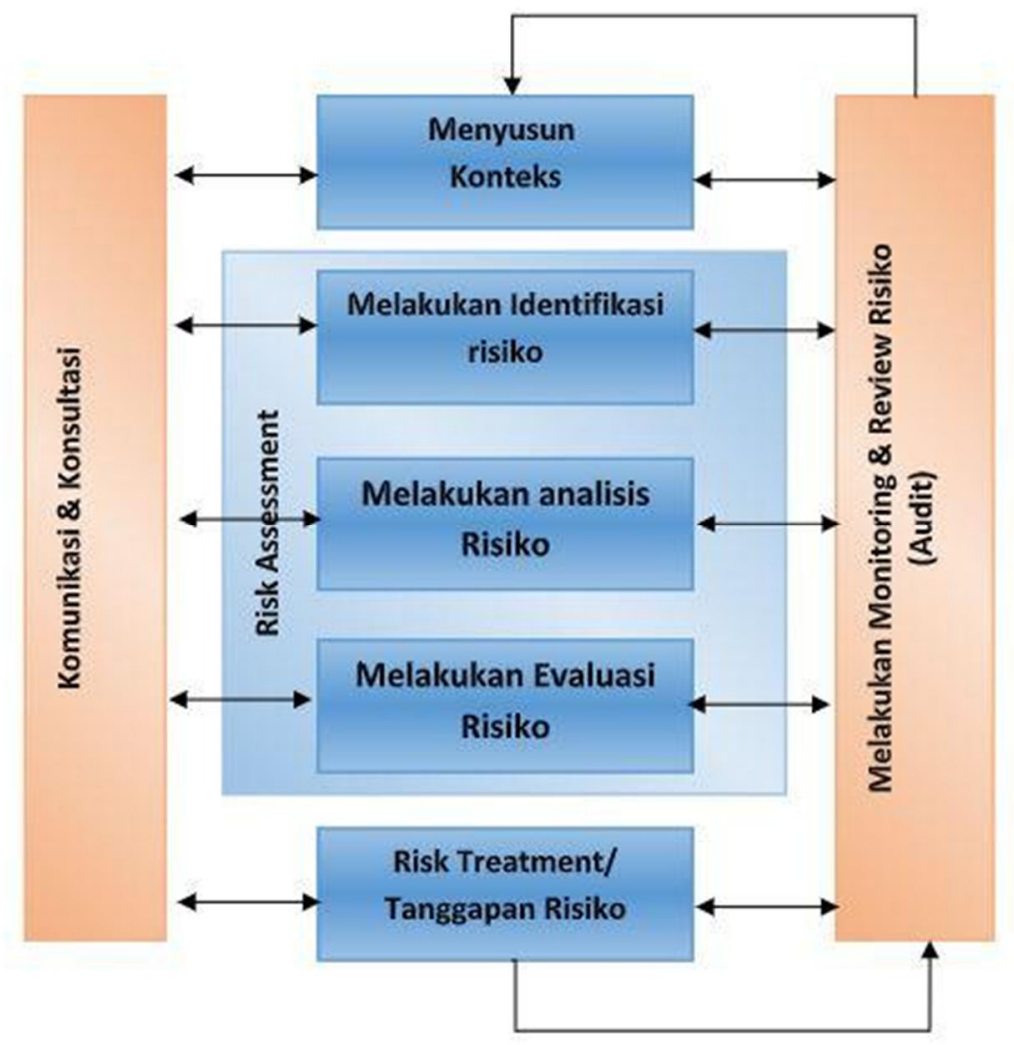

Gambar 1. Tahapan Analisis Risiko

Tahap pertama yang dilakukan adalah perencanaan. Sebelum melakukan penelitian, peneliti wajib menentukan metode apa yang digunakan. Dalam pengambilan data, peneliti menggunakan metode kualitatif dengan wawancara. Sebelum wawancara, peneliti menyusun daftar pertanyaan untuk wawancara. Lalu memilih siapa informan kunci. Peneliti memilih 7 informan kunci di bidang industri yang terdiri dari Kepala Bidang, Kepala Sie Pengembangan Industri, Kepala Sie Sistem Informasi Industri, pranata komputer, dan beberapa staff pegawai. Saat melakukan sesi wawancara, peneliti merekam dan menulis hasil wawancara agar menjaga keaslian data. Setelah wawancara, peneliti mengidentifikasi lingkungan internal bidang industri Disperinnaker Kota Salatiga.

Tahap kedua adalah identifikasi risiko. Pada tahap ini, peneliti menentukan sasaran agar risiko dapat diidentifikasi, diakses, dan dikelola sesuai dengan tujuan. Mengidentifikasi kejadian yang mempengaruhi strategi atau pencapaian tujuan dari organisasi yang berdampak positif (opportunities), namun dapat juga sebagai risiko (risk). Setelah diidentifikasi, peneliti membuat rentangan nilai untuk risiko yang ada.

Tahap ketiga adalah penanganan. Pada tahap ini, peneliti mengelompokkan kemungkinan risiko yang sudah diidentifikasi lalu membuat dan menentukan alternatif terbaik untuk setiap risiko yang ada.

Tahap keempat adalah monitoring. Pada tahap ini, peneliti harus melakukan evaluasi untuk memperhatikan kendala apa saja yang terjadi setelah dibuatnya alternatif risiko. Dan melakukan monitoring berkelanjutan untuk melihat bagaimanakah dampak dari perlakuan risiko untuk menangani setiap risiko. 


\subsection{ISO 31000}

ISO 31000 merupakan pedoman standar, instruksi, dan tuntutan bagi sebuah organisasi untuk membangun sebuah pondasi dan kerangka kerja bagi suatu program manajemen risiko. ISO 31000 memberikan pedoman dan prinsip untuk mengelola segala jenis risiko secara sistematis, transparan, dan andal dalam ruang lingkup dan konteks apapun[8]. Terdapat 11 (sebelas) prinsip yang diterapkan pada kerangka kerja untuk memastikan efektifitasnya, yaitu memberikan nilai tambah dan melindungi nilai organisasi, bagian terpadu dari seluruh proses organisasi, bagian dari pengambilan keputusan, secara khusus menangani ketidakpastian, sistematis terstruktur dan tepat waktu, berdasarkan informasi terbaik yang tersedia, disesuaikan dengan kebutuhan organisasi, mempertimbangkan faktor budaya dan manusia, transparan dan inklusif, dinamis berulang dan responsif terhadap perubahan, memfasilitasi perbaikan sinambung dan peningkatan organisasi. Dapat dilihat pada gambar 2.

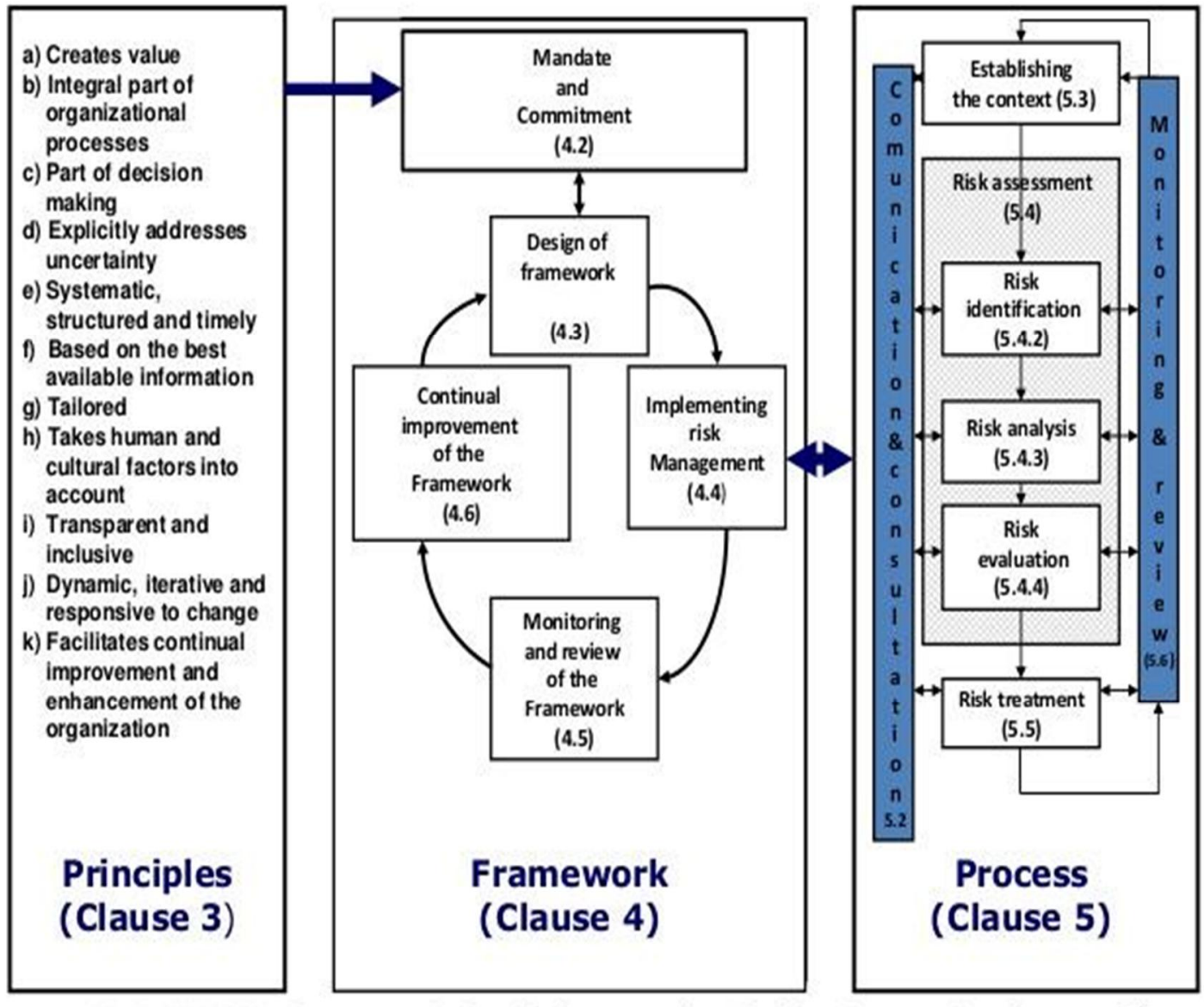

ISO 31000:2009 Figure 1 - Relationship between the principles, framework and process ${ }^{74}$

Gambar 2. Kerangka Kerja ISO 31000:2009

Kerangka kerja analisis risiko menggunakan prinsip ISO 31000 mencakup pemahaman mengenai organisasi dan konteksnya, menetapkan kebijakan analisis risiko, menetapkan akuntabilitas analisis risiko, mengintegrasikan manajemen risiko dalam proses bisnis organisasi, alokasi sumber daya manajemen risiko, dan menetapkan mekanisme komunikasi internal dan eksternal[9]Kerangka kerja dimulai dari pemberian mandat dan komitmen. Pemberian mandat dan komitmen meliputi penentuan akuntabilitas, kewenangan, dan kapabilitas dari pelaku 
analisis risiko. Setelah itu implementasi Plan, Do, Check, Act. Yaitu perencanaan, penerapan, monitoring dan review, dan perbaikan [10].

Langkah pertama yang dilakukan yaitu penetapan konteks (establishing the context) yang bertujuan untuk mengidentifikasi dan mengungkapkan sasaran organisasi, lingkungan dimana sasaran hendak dicapai, stakeholders yang berkepentingan, dan keberagaman kriteria risiko.

Langkah kedua adalah penilaian risiko (risk assessment), yang terdiri dari beberapa tahap, yaitu identifikasi risiko, analisis risiko, dan evaluasi risiko. Identifikasi risiko adalah mengidentifikasi risiko apa saja yang dapat mempengaruhi pencapaian sasaran organisasi. Analisis risiko adalah menganalisis kemungkinan dan dampak dari risiko yang telah diidentifikasi. Evaluasi risiko adalah membandingkan hasil analisis risiko dengan kriteria risiko untuk menentukan bagaimana penanganan risiko yang akan diterapkan.

Langkah yang ketiga adalah perlakuan risiko (risk treatment) yaitu dengan mitigasi risiko. Pada proses ini, peneliti memberikan saran atau usulan untuk memperlakukan kemungkinan risiko yang telah teridentifikasi.

\section{HASIL DAN PEMBAHASAN}

\subsection{Penilaian Risiko}

Pada proses penilaian risiko, dilakukan 3 tahapan yang sesuai dengan pedoman analisis risiko menggunakan metode ISO 31000. 3 tahap penilaian tersebut adalah tahap identifikasi risiko, tahap analisis risiko, dan tahap evaluasi risiko.

\subsubsection{Identifikasi Risiko}

Tahap pertama yang dilakukan dalam penilaian risiko adalah tahap identifikasi risiko (risk identification). Dalam proses ini dilakukan wawancara untuk mengidentifikasi aset dan aplikasi yang berhubungan dengan bidang industri Disperinnaker Kota Salatiga [11]. Dengan tujuan untuk mengetahui risiko yang muncul dari berbagai faktor yang akan mengancam , seperti lingkungan, infrastruktur, manusia, dan sistem. Detail aset yang diidentifikasi, akan dijelaskan pada tabel 1 .

Tabel 1. Data Aset Bidang Industri

\begin{tabular}{cll}
\hline Komponen & \multicolumn{1}{c}{ Data Aset } \\
\hline \multirow{2}{*}{ Data } & 1. Data Pegawai \\
& 2. Data User Bidang Industri \\
& 3. Data Informasi \\
\hline \multirow{3}{*}{ Software } & 1. SIINas \\
& 2. SIIDa \\
& 3. SIMASTRI \\
\hline \multirow{3}{*}{ Hardware } & 1. Komputer (PC) \\
& 2. Server Database \\
& 3. Server Web Service \\
& 4. CCTV \\
\hline
\end{tabular}

Setelah melakukan identifikasi pada aset, selanjutnya melakukan identifikasi risiko pada software atau aplikasi yang digunakan. Ada 3 aplikasi yang digunakan bidang industri, yang pertama yaitu SIINas. Sistem Informasi Industri Nasional (SIINAS) adalah suatu sistem informasi yang berisi data dan informasi tentang industri nasional yang digunakan oleh perusahaan, asosiasi industri, pengelola kawasan industri, pemda, masyarakat, serta kalangan 
internal kementerian perindustrian. Sistem pengumpulan datanya adalah penyampaian laporan secara online.

Yang kedua adalah Sistem Informasi Industri Daerah Provinsi Jawa Tengah (SIIDa). Pada tahun 2020 Dinas Perindustrian dan Perdagangan Provinsi Jawa Tengah mengadakan launching SIIDa dan menyelenggarakan training yang diikuti oleh 20 personil internal Dinas dari bidang industri agro, non agro, dan sekretariat. Dengan data di dalamnya ada nama perusahaan, alamat perusahaan, jenis produk, bahan baku, produksi / tahun, tenaga kerja, dan skala industri.

Yang ketiga adalah SIMASTRI. Aplikasi buatan Disperinnaker bidang industri Kota Salatiga yang bertujuan untuk menghubungkan aktivitas antara dinas dengan pihak industri masyarakat (UKM dan UMKM). Dengan pelaporan online secara berkala meliputi kegiatan yang dilakukan, dokumentasi, dan masalah yang terjadi.

Identifikasi risiko tentang software atau aplikasi bidang industri akan dijelaskan pada tabel 2.

Tabel 2. Identifikasi Risiko Software / Aplikasi Bidang Industri

\begin{tabular}{cl}
\hline Software & \multicolumn{1}{c}{ Identifikasi Risiko Software } \\
\hline SIINas & $\begin{array}{l}\text { Belum terintegrasinya OSS dengan sistem Kemenkominfo, sehingga proses } \\
\text { pengeluaran izin memakan waktu lama. }\end{array}$ \\
\hline SIIDa & $\begin{array}{l}\text { Bidang industri kurang mengerti tentang penggunaan aplikasi SIIDa. } \\
\text { Tampilan user interface antara bidang industri dan pihak masyarakat berbeda. }\end{array}$ \\
\hline SIMASTRI & $\begin{array}{l}\text { Banyak terjadi double account. } \\
\text { Bidang industri masih manual dalam membalas email untuk meminta username } \\
\text { dan password pembuatan akun SIMASTRI. }\end{array}$ \\
\hline
\end{tabular}

Dari hasil identifikasi aset dan aplikasi diatas, dapat ditemukan beberapa kemungkinan risiko yang akan menghasilkan dampak. Kemungkinan risiko dan dampak risiko tersebut akan dijabarkan pada tabel 3 .

Tabel 3. Kemungkinan Risiko

\begin{tabular}{|c|c|c|}
\hline ID & $\begin{array}{l}\text { Kemungkinan } \\
\text { Risiko }\end{array}$ & Dampak Risiko \\
\hline KR001 & Program crash & $\begin{array}{l}\text { 1. Pada aplikasi SIINas, Pemda harus memasukkan data secara } \\
\text { manual sehingga menyebabkan proses pengeluaran izin } \\
\text { perindustrian memakan waktu lama. } \\
\text { 2. Pada aplikasi SIIDa, banyak pihak masyarakat dan bidang } \\
\text { industri Kota Salatiga tidak bisa mengaplikasikannya secara } \\
\text { optimal. Dan kurang lengkapnya tutorial tentang aplikasi } \\
\text { SIIDa. } \\
\text { 3. Pada aplikasi SIMASTRI, banyak terjadi crash dalam } \\
\text { pengiriman email untuk meminta username dan password, } \\
\text { sehingga banyak terjadi double account. Dan dalam } \\
\text { pengecekan email masih secara manual, sehingga banyak } \\
\text { email yang tertumpuk. }\end{array}$ \\
\hline KR002 & $\begin{array}{l}\text { Kehilangan } \\
\text { data }\end{array}$ & $\begin{array}{l}\text { Hilangnya data pegawai dan user (peserta industri dari pihak } \\
\text { masyarakat), karena masih ditulis secara manual. }\end{array}$ \\
\hline KR003 & Server down & $\begin{array}{l}\text { 1. Menghambat proses bisnis yang sedang berjalan dalam bidang } \\
\text { industri. } \\
\text { 2. Aplikasi yang ada digunakan menjadi error / tidak dapat } \\
\text { berjalan dengan baik. }\end{array}$ \\
\hline
\end{tabular}

Andeka, et., al [Analisis Risiko Dengan Metode ISO 31000 Pada Disperinnaker Kota Salatiga Bidang Industri] 


\begin{tabular}{|c|c|c|}
\hline KR004 & $\begin{array}{l}\text { Kerusakan } \\
\text { pada hardware }\end{array}$ & $\begin{array}{l}\text { 1. Mengurangi jumlah aset pada dinas. } \\
\text { 2. Mengurangi kinerja para pegawai. }\end{array}$ \\
\hline KR005 & $\begin{array}{l}\text { Overheat / } \\
\text { overload }\end{array}$ & $\begin{array}{l}\text { Komputer (PC) yang digunakan menjadi lambat atau error } \\
\text { sehingga berdampak pada kinerja pegawai. }\end{array}$ \\
\hline KR006 & $\begin{array}{l}\text { Maintenance } \\
\text { tidak terjadwal }\end{array}$ & $\begin{array}{l}\text { Melemahnya kapasitas komputer (pc) sehingga tidak dapat } \\
\text { maksimal dalam penggunaannya. }\end{array}$ \\
\hline KR007 & $\begin{array}{l}\text { CCTV tidak } \\
\text { berfungsi } \\
\text { dengan baik }\end{array}$ & $\begin{array}{l}\text { 1. Pemantauan proses kerja di Disperinnkaer menjadi kurang } \\
\text { efektif, karena ruang pemantau CCTV berada pada ruang } \\
\text { Kepala Dinas. Sehingga hanya Kepala Dinas saja yang dapat } \\
\text { memantau. } \\
\text { 2. Berkurangnya tingkat keamanan saat Kepala Dinas tidak } \\
\text { berada dalam ruangan, karena tidak ada yang memantau. }\end{array}$ \\
\hline KR008 & $\begin{array}{l}\text { Penyalahgunaa } \\
\text { n hak akses } \\
\text { (human error) }\end{array}$ & Bocornya data perusahaan \\
\hline KR009 & $\begin{array}{l}\text { Teknologi tidak } \\
\text { terupdate }\end{array}$ & $\begin{array}{l}\text { 1. Proses kerja melambat. } \\
\text { 2. Disperinnaker menjadi sulit untuk berkembang dan tidak } \\
\text { mengikuti trend (terutama selama masa pandemi Covid-19) }\end{array}$ \\
\hline KR010 & $\begin{array}{l}\text { Aplikasi yang } \\
\text { susah dipahami }\end{array}$ & $\begin{array}{l}\text { Selama musim pandemi banyak aplikasi yang digunakan, } \\
\text { dinas harus bisa mengaplikasikan aplikasi tersebut untuk } \\
\text { mendukung kegiatan sehari-hari. Sehingga perlu diadakannya } \\
\text { training untuk latihan dalam menggunakan aplikasi. }\end{array}$ \\
\hline KR011 & $\begin{array}{l}\text { Dokumentasi } \\
\text { program yang } \\
\text { kurang lengkap }\end{array}$ & Memperlambat proses kerja pada Dinas. \\
\hline KR012 & $\begin{array}{l}\text { Koneksi } \\
\text { jaringan tidak } \\
\text { stabil }\end{array}$ & $\begin{array}{l}\text { Menghambat kegiatan pegawai yang menggunakan koneksi } \\
\text { internet. }\end{array}$ \\
\hline KR013 & Listrik padam & $\begin{array}{l}\text { 1. Kerugian operasional Dinas karena tidak adanya genset. } \\
\text { 2. Mengganggu proses kerja server (kualitas server menurun). }\end{array}$ \\
\hline KR014 & Bencana alam & $\begin{array}{l}\text { 1. Kerusakan infrastruktur pada Dinas. } \\
\text { 2. Aktivitas pegawai terhambat. }\end{array}$ \\
\hline
\end{tabular}

\subsubsection{Analisis Risiko}

Setelah data identifikasi risiko terkumpul, kemudian dilakukan analisis risiko. Proses ini bertujuan untuk menentukan nilai kemungkinan risiko yang sudah teridentifikasi. Dalam menentukan nilai risiko, menggunakan tabel likelihood. Likelihood merupakan kriteria risiko yang akan menjadi dasar pengukuran setiap risiko dan kemungkinan terjadinya [12]. Yang akan dijelaskan pada tabel 4.

Tabel 4. Likelihood

\begin{tabular}{cclc}
\hline Nilai & Kriteria & \multicolumn{1}{c}{ Deskripsi } & Frekuensi Kejadian \\
\hline 1 & Rare & Risiko tersebut hampir tidak pernah terjadi. & $>2$ tahun \\
2 & Unlikely & Risiko tersebut jarang terjadi. & $1-2$ tahun \\
3 & Possible & Risiko tersebut kadang terjadi. & $7-12$ bulan \\
4 & Likely & Risiko tersebut sering terjadi. & $4-6$ bulan \\
5 & Certain & Risiko tersebut pasti terjadi. & $1-3$ bulan \\
\hline
\end{tabular}

Kriteria tersebut dibedakan dari dampak yang tidak berpengaruh sampai dampak yang paling berpengaruh bagi jalannya aktivitas pada Dinas. Setelah kemungkinan risiko diukur 
dengan kriteria likelihood[13], selanjutnya memasukkan data analisis ke dalam tabel impact (tabel dampak) sesuai dengan kriteria yang didapat. Yang akan dibahas pada tabel 5.

Tabel 5. Impact

\begin{tabular}{ccl}
\hline Nilai & Kriteria & \multicolumn{1}{c}{ Keterangan } \\
\hline 1 & $\begin{array}{c}\text { Insignificant } \\
\text { Minor }\end{array}$ & $\begin{array}{l}\text { Risiko tersebut tidak mengganggu jalannya aktivitas Dinas. } \\
\text { Risiko tersebut sedikit menghambat, namun aktivitas inti } \\
\text { pada Dinas tidak terganggu. } \\
\text { Risiko tersebut menyebabkan gangguan pada proses bisnis } \\
\text { yang ada, sehingga sebagian jalannya aktivitas pada Dinas } \\
\text { terhambat. }\end{array}$ \\
4 & Moderate & $\begin{array}{l}\text { Risiko tersebut hampir menghambat seluruh jalannya } \\
\text { aktivitas Dinas. } \\
\text { Risiko tersebut membuat aktivitas berhenti karena proses } \\
\text { bisnis mengalami gangguan total. }\end{array}$ \\
\hline
\end{tabular}

Setelah menentukan kriteria nilai kemungkinan (likelihood) dan dampak (impact), selanjutnya melakukan tahap penilaian terhadap kemungkinan risiko yang ada. Kemungkinan risiko dapat dilihat pada tabel 6 .

Tabel 6. Penilaian Likelihood dan Impact

\begin{tabular}{clcc}
\hline ID & \multicolumn{1}{c}{ Kemungkinan Risiko } & Likelihood & Impact \\
\hline KR001 & Program crash & 3 & 3 \\
KR002 & Kehilangan data & 2 & 3 \\
KR003 & Server down & 5 & 4 \\
KR004 & Kerusakan pada hardware & 5 & 2 \\
KR005 & Overheat / overload & 4 & 4 \\
KR006 & Maintenance tidak terjadwal & 2 & 2 \\
KR007 & CCTV tidak berfungsi dengan baik & 3 & 1 \\
KR008 & Penyalahgunaan hak akses (human error) & 1 & 2 \\
KR009 & Teknologi tidak terupdate & 2 & 2 \\
KR010 & Aplikasi yang susah dipahami & 2 & 2 \\
KR011 & Dokumentasi program yang kurang & 3 & 2 \\
& lengkap & & \\
KR012 & Koneksi jaringan tidak stabil & 5 & 2 \\
KR013 & Listrik padam & 3 & 5 \\
KR014 & Bencana alam & 1 & 5 \\
\hline
\end{tabular}

Setelah melakukan analisis risiko melalui tabel likelihood, dapat disimpulkan bahwa pada kriteria rare (hampir tidak pernah terjadi) terdapat 2 (dua) kemungkinan risiko yang terjadi. Yaitu penyalahgunaan hak akses (human error) dan bencana alam. Pada kriteria unlikely (jarang terjadi) terdapat 4 (empat) kemungkinan risiko yang terjadi, yaitu kehilangan data, maintenance tidak terjadwal, teknologi tidak terupdate, dan aplikasi yang susah dipahami. Pada kriteria possible (kadang terjadi) terdapat 4 (empat) kemungkinan risiko yang terjadi, yaitu program crash, CCTV tidak berfungsi dengan baik, dokumentasi program kurang lengkap, dan listrik padam. Pada kriteria likely (sering terjadi) terdapat 1 (satu) kemungkinan risiko yang terjadi, yaitu overheat / overload. Pada kriteria certain (pasti terjadi) terdapat 3 (tiga) kemungkinan risiko yang terjadi, yaitu server down, kerusakan pada hardware, dan koneksi jaringan tidak stabil. 
Hasil analisis risiko melalui tabel impact (dampak) mendapatkan hasil bahwa dampak insignificant terdapat 1 (satu) kemungkinan risiko, yaitu CCTV yang tidak berfungsi dengan baik. Dampak minor terdapat 7 (tujuh) kemungkinan risiko, yaitu kerusakan pada hardware, maintenance tidak terjadwal, penyalahgunaan hak akses (human error), teknologi tidak terupdate, aplikasi yang susah dipahami, dokumentasi program kurang lengkap, dan koneksi jaringan tidak stabil. Dampak moderate terdapat 2 (dua) kemungkinan risiko, yaitu program crash dan kehilangan data. Dampak major terdapat 2 (dua) kemungkinan risiko, yaitu server down dan overheat / overload.Dampak catastrophic terdapat 2 (dua) kemungkinan risiko, yaitu listrik padam dan bencana alam.

\subsubsection{Evaluasi Risiko}

Setelah analisis risiko, dilakukan tahap evaluasi risiko. Pada tahap ini dilakukan evaluasi risiko dari kemungkinan risiko yang sudah diidentifikasi sebelumnya [14]. Hasil dari analisis tersebut, akan dimasukkan kedalam tabel matrix evaluasi risiko berdasarkan pedoman yang ada di dalam kerangka kerja ISO 31000. Tabel tersebut akan dijelaskan pada gambar 3.

\begin{tabular}{|c|c|c|c|c|c|c|c|}
\hline \multirow{5}{*}{ 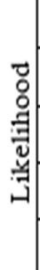 } & Certain & 5 & Medium & Medium & High & High & High \\
\hline & Likely & 4 & Medium & Medium & Medium & High & High \\
\hline & Possible & 3 & Low & Medium & Medium & Medium & High \\
\hline & Unlikely & 2 & Low & Low & Medium & Medium & Medium \\
\hline & Rare & 1 & Low & Low & Low & Medium & Medium \\
\hline \multirow{2}{*}{\multicolumn{3}{|c|}{ Impact }} & 1 & 2 & 3 & 4 & 5 \\
\hline & & & Insignificant & Minor & Moderate & Major & Catastrophic \\
\hline
\end{tabular}

Gambar 3. Matrix Evaluasi Risiko

Pada bagian matrix akan dilakukan evaluasi risiko berdasarkan dari identitas yang dimiliki oleh kemungkinan risiko, untuk dimasukkan ke dalam parameter sesuai kriteria pada tabel likelihood dan impact yang akan dijelaskan pada tabel 7.

Tabel 7. Matrix Evaluasi Risiko Kemungkinan Risiko

\begin{tabular}{|c|c|c|c|c|c|c|}
\hline \multirow{8}{*}{ 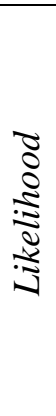 } & \multirow[t]{2}{*}{5} & & KR004 & & \multirow[t]{2}{*}{ KR003 } & \\
\hline & & & KR012 & & & \\
\hline & 4 & & & & KR00 & \\
\hline & 3 & KR007 & KR011 & KR001 & & KR013 \\
\hline & 2 & & KR006 & KR002 & & \\
\hline & & & KR009 & & & \\
\hline & & & KR010 & & & \\
\hline & 1 & & KR008 & & & KR014 \\
\hline & & 1 & 2 & 3 & 4 & 5 \\
\hline
\end{tabular}

Setelah kemungkinan risiko dimasukkan dalam matrix evaluasi risiko, selanjutnya akan dijelaskan ke dalam tabel 8 tentang level risiko setiap kemungkinan risiko. 
Tabel 8. Level Risiko

\begin{tabular}{clccc}
\hline ID & \multicolumn{1}{c}{ Kemungkinan Risiko } & Likelihood & Impact & Level Risiko \\
\hline KR003 & Server down & 5 & 4 & High \\
KR005 & Overheat/overload & 4 & 4 & High \\
KR013 & Listrik padam & 3 & 5 & High \\
KR001 & Program crash & 2 & 3 & Medium \\
KR002 & Kehilangan data & 5 & 2 & Medium \\
KR004 & Kerusakan pada hardware & 3 & 2 & Medium \\
KR011 & Dokumentasi program kurang lengkap & 5 & 2 & Medium \\
KR012 & Koneksi jaringan tidak stabil & 3 & 3 & Medium \\
KR014 & Bencana alam & 1 & 5 & Medium \\
KR006 & Maintenance tidak terjadwal & 2 & 2 & Low \\
KR007 & CCTV tidak berfungsi dengan baik & 3 & 1 & Low \\
KR008 & Penyalahgunaan hak akses (human & 1 & 2 & Low \\
& error) & & & \\
KR009 & Teknologi tidak terupdate & 2 & 2 & Low \\
KR010 & Aplikasi yang susah dipahami & 3 & 2 & Low \\
\hline
\end{tabular}

Dari hasil evaluasi risiko, terdapat 3 kemungkinan risiko yang masuk kedalam level of risk tingkatan high yaitu server down, overheat/overload, dan listrik padam. Ada 6 kemungkinan risiko yang masuk kedalam level of risk tingkatan medium yaitu program crash, kehilangan data, kerusakan pada hardware, dokumentasi program yang kurang lengkap, koneksi jaringan tidak stabil, bencana alam. Serta terdapat 5 kemungkinan risiko yang masuk kedalam level of risk tingkat low yaitu maintenance tidak terjadwal, CCTV tidak berfungsi dengan baik, penyalahgunaan hak akses (human error), teknologi tidak terupdate, aplikasi yang susah dipahami.

\subsection{Perlakuan Risiko}

Setelah dilakukan proses penilaian risiko yang meliputi identifikasi risiko, analisis risiko, dan evaluasi risiko. Selanjutnya akan dilakukan proses perlakuan risiko. Pada tahap ini, akan diberikan saran dan usulan dalam memperlakukan risiko - risiko yang telah teridentifikasi dengan harapan dapat meminimalisir munculnya risiko tersebut, sehingga semua aktivitas dapat berjalan secara optimal [15]. Dapat dilihat pada tabel 9 tentang kategori perlakuan risiko.

Tabel 9. Kategori Perlakuan Risiko

\begin{tabular}{ll}
\hline \multicolumn{1}{c}{ Kategori } & \multicolumn{1}{c}{ Keterangan } \\
\hline Risk avoidance & $\begin{array}{l}\text { Digunakan untuk menghindari risiko dengan menghilangkan } \\
\text { penyebab dan atau konsekuensi risiko. }\end{array}$ \\
Risk reduction & $\begin{array}{l}\text { Digunakan dengan mengurangi kemungkinan atau dampak. } \\
\text { Risk acceptance } \\
\text { Dapat menerima risiko yang berarti sama dengan menanggung } \\
\text { seluruh tanggung jawab atas risiko yang terjadi. }\end{array}$ \\
Risk sharing & $\begin{array}{l}\text { Digunakan untuk mentransfer risiko dengan menggunakan opsi } \\
\text { lain untuk mengurangi dampak. }\end{array}$ \\
\hline
\end{tabular}

Setiap risiko akan diberikan perlakuan risiko sesuai dengan kemungkinan risiko yang terjadi. Dalam melakukan perlakuan risiko akan dijelaskan bagaimana level setiap kemungkinan risiko, saran atau usulan dalam memperlakukan risiko, dan kategori dalam perlakuan risiko. Berikut adalah tabel 10, yaitu tabel perlakuan risiko sesuai kemungkinan risiko. 
Tabel 10. Perlakuan Risiko Sesuai Kemungkinan Risiko

\begin{tabular}{|c|c|c|c|}
\hline ID & Level Risiko & Perlakuan Risiko & Kategori \\
\hline KR003 & High & $\begin{array}{l}\text { 1. Melakukan pengecekan secara berkala } \\
\text { pada server. } \\
\text { 2. Melakukan refresh penggunaan db log, } \\
\text { temp, dan RAM yang digunakan. } \\
\text { 3. Mengaplikasikan database dengan skala } \\
\text { lebih besar lagi. }\end{array}$ & Risk reduction \\
\hline KR005 & High & $\begin{array}{l}\text { 1. Melakukan pengecekan secara berkala. } \\
\text { 2. Memantau suhu processor agar tidak } \\
\text { mudah panas. Bisa dengan bantuan } \\
\text { aplikasi. } \\
\text { 3. Bersihkan virus secara teratur. }\end{array}$ & Risk avoidance \\
\hline KR013 & High & $\begin{array}{l}\text { 1. Menggunakan fasilitas genset. } \\
\text { 2. Selalu melakukan konfirmasi dengan PLN } \\
\text { atas gangguan yang terjadi. }\end{array}$ & Risk sharing \\
\hline KR001 & Medium & $\begin{array}{l}\text { 1. Pada aplikasi SIINas, sebaiknya bidang } \\
\text { industri mengelompokkan identitas pidak } \\
\text { industri masyarakat untuk ditampung } \\
\text { dalam satu file atau aplikasi, sehingga saat } \\
\text { dibutuhkan data sudah tersedia. } \\
\text { 2. Pada aplikasi SIIDa, sebaiknya bidang } \\
\text { industri memiliki SOP yang jelas dalam } \\
\text { mengaplikasikan aplikasi tersebut. Agar } \\
\text { saat terjadi keluhan dari masyarakat, } \\
\text { bidang industri dapat menjawab. } \\
\text { 3. Pada aplikasi SIMASTRI, bidang industri } \\
\text { sebaiknya memberikan kebijakan (syarat) } \\
\text { bahwa email yang sudah meminta } \\
\text { username dan password untuk pembuatan } \\
\text { akun, tidak dapat meminta ulang kecuali } \\
\text { lupa password. Agar terhindar dari double } \\
\text { account dan penumpukan. }\end{array}$ & Risk reduction \\
\hline KR002 & Medium & $\begin{array}{l}\text { 1. Mengaplikasikan password pada setiap } \\
\text { data yang penting. } \\
\text { 2. Memiliki back up data file pada tempat } \\
\text { lain. } \\
\text { 3. Melakukan pemantauan melalui CCTV. }\end{array}$ & Risk avoidance \\
\hline KR004 & Medium & 1. Melakukan perawatan secara berkala & Risk reduction \\
\hline KR011 & Medium & $\begin{array}{l}\text { 1. Setiap mengaplikasikan program harus } \\
\text { sesuai dan jelsa terhadap SOP agar saat } \\
\text { terjadi masalah ada prosedur untuk } \\
\text { pembetulannya. } \\
\text { 2. Selalu mendokumentasikan suatu program } \\
\text { agar dapat dipakai oleh generasi } \\
\text { selanjutnya. } \\
\text { 3. Membuat knowledge management system } \\
\text { untuk mendokumentasikan pengetahuan. }\end{array}$ & Risk reduction \\
\hline KR012 & Medium & $\begin{array}{l}\text { 1. Meminta kuota tambahan jaringan wifi } \\
\text { pada Diskominfo agar lebih lancar dalam }\end{array}$ & Risk reduction \\
\hline
\end{tabular}




\begin{tabular}{|c|c|c|c|}
\hline & & $\begin{array}{l}\text { menggunakan wifi. } \\
\text { 2. Mengganti ISP dengan yang lebih baik. }\end{array}$ & \\
\hline KR014 & Medium & $\begin{array}{l}\text { 1. Menyimpan aset atau data pada tempat } \\
\text { yang aman. } \\
\text { 2. Memasang server cadangan atau backup } \\
\text { data pada lokasi yang berbeda. }\end{array}$ & $\begin{array}{c}\text { Risk } \\
\text { acceptance }\end{array}$ \\
\hline KR006 & Low & 1. Melakukan penjadwalan maintenance. & Risk reduction \\
\hline KR007 & Low & $\begin{array}{l}\text { 1. Ruang pemantau CCTV sebaiknya } \\
\text { ditempatkan pada ruang yang selalu } \\
\text { diawasi agar jika terjadi sesuatu dapat } \\
\text { segera diatasi. }\end{array}$ & Risk reduction \\
\hline KR008 & Low & $\begin{array}{l}\text { 1. Mengaplikasikan password pada setiap PC. } \\
\text { 2. Melakukan training dan bimbingan untuk } \\
\text { pegawai baru. }\end{array}$ & $\begin{array}{l}\text { Risk avoidance } \\
\text { Risk reduction }\end{array}$ \\
\hline KR009 & Low & $\begin{array}{l}\text { 1. Selalu mengikuti perkembangan teknologi } \\
\text { agar tercapai tujuan e-government yang } \\
\text { baik. }\end{array}$ & Risk reduction \\
\hline KR010 & Low & $\begin{array}{l}\text { 1. Melakukan penyuluhan dan training } \\
\text { tentang aplikasi terbaru. }\end{array}$ & Risk reduction \\
\hline
\end{tabular}

Dari hasil perlakuan risiko, terdapat 3 (tiga) kemungkinan risiko yang masuk dalam kategori risk avoidance, yaitu penyalahgunaan hak akses (human error), overheat/overload, dan kehilangan data. Terdapat 10 (sepuluh) kemungkinan risiko yang masuk dalam kategori risk reduction, yaitu server down, program crash, kerusakan pada hardware, dokumentasi program yang kurang lengkap, koneksi jaringan tidak stabil, maintenance tidak terjadwal, CCTV tidak berfungsi dengan baik, penyalahgunaan hak akses (human error), teknologi tidak terupdate, dan aplikasi susah dipahami. Terdapat 1 (satu) kemungkinan risiko yang masuk dalam kategori risk acceptance, yaitu bencana alam. Serta terdapat 1 (satu) kemungkinan risiko yang masuk dalam kategori risk sharing, yaitu listrik padam.

\section{KESIMPULAN}

Berdasarkan penelitian analisis risiko dengan menggunakan metode ISO 31000 pada Dinas Perindustrian dan Tenaga Kerja (Disperinnaker) Kota Salatiga di bidang Industri, didapatkan hasil, bahwa ada 14 kemungkinan risiko yang mengganggu jalannya aktivitas kegiatan pada bidang industri Disperinnaker Kota Salatiga. Dari 14 kemungkinan risiko, ada 3 (tiga) yang masuk ke dalam risiko tinggi (high level), 6 (enam) yang masuk ke dalam medium level, 5 (lima) yang masuk dalam level rendah (low level).

\section{SARAN}

Saran untuk penelitian kedepannya agar peneliti dapat menganalisis proses setiap kinerja yang ada pada Dinas Industri Kota Salatiga demi kelancaran pemenuhan tugas organisasi. 


\section{DAFTAR PUSTAKA}

[1] S. Agustinus, A. Nugroho, and A. D. Cahyono. 2017, "Analisis Risiko Teknologi Informasi Menggunakan ISO 31000 pada Program HRMS,” J. RESTI (Rekayasa Sist. dan Teknol. Informasi), Vol. 1, No. 3, pp. 250-258, doi: 10.29207/resti.v1i3.94.

[2] S. A. Sherer and S. Alter. 2014, "Information Systems Risks and Risk Factors: Are They Mostly About Information Systems?,” Commun. Assoc. Inf. Syst., Vol. 14, No. May 2014, doi: 10.17705/1cais.01402.

[3] N. Student et al. 2014, "Developing A Risk Management System for Information Systems Security Incidents," Georg. Inst. Technol. Copyr., Vol. 28, No. 1, pp. 1-6, [Online]. Available: http://www.sba-research.org

[4] G. Stoneburner, A. Goguen, and A. Feringa. 2002, "Risk Management Guide for Information Technology Systems (Special Publication 800-30). Gaithersburg, MD: National Institute of Standards and Technology,"

[5] H. Očevčić, K. Nenadić, K. Šolić, and T. Keser. 2017, "The Impact of Information System Risk Management On The Frequency and Intensity of Security Incidents," Int. J. Electr. Comput. Eng. Syst., Vol. 8, No. 2, pp. 41-46, doi: 10.32985/ijeces.8.2.1.

[6] S. Amraoui, M. Elmaallam, H. Bensaid, and A. Kriouile. 2019, "Information Systems Risk Management: Litterature Review,” Comput. Inf. Sci., Vol. 12, No. 3, p. 1, doi: 10.5539/cis.v12n3p1.

[7] O. Đurković and L. Raković. 2009, "Risks in Information Systems Development Projects," Management, Vol. 4, No. 1, pp. 013-019,

[8] V. Cantino, P. De Vincentiis, and G. Racca. 2016, "Risk Management: Risk Management:," Vol. 51, No. 4, pp. 1-12,

[9] M. Leitch. 2010, "ISO 31000:2009 - The New International Standard on Risk Management: Perspective," Risk Anal., Vol. 30, No. 6, pp. 887-892, doi: 10.1111/j.15396924.2010.01397.x.

[10] S. N. Luko. 2013, “Risk Management Principles and Guidelines," Qual. Eng., Vol. 25, No. 4, pp. 451-454, doi: 10.1080/08982112.2013.814508.

[11] M. Miftakhatun. 2020, "Analisis Manajemen Risiko Teknologi Informasi pada Website Ecofo Menggunakan ISO 31000,” J. Comput. Sci. Eng., Vol. 1, No. 2, pp. 128-146, doi: 10.36596/jcse.v1i2.76.

[12] F. F. Sudarsono, R. W. Saputra, N. Sani, N. F. Nisa, I. Jannah, and I. S. Rozas. 2018, "Analisis Manajemen Risiko Berdasarkan ISO 31000 pada Pesantren Luhur AlHusna Wonocolo Surabaya - Jurnal Ekonomi dan Manajemen Vol.11 No.12014,” pp. 160-173.

[13] B. Baharuddin and M. M. Yusof, "Evaluation of Risk Management Practices In Information Systems Project In The Public Sector,” J. Pengur., Vol. 53, No. 2018, pp. 23-36, 2018, doi: 10.17576/pengurusan-2018-52-03. 
[14] K. B. Mahardika, A. F. Wijaya, and A. D. Cahyono. 2019, "Manajemen Risiko Teknologi Informasi Menggunakan Iso 31000: 2018 (Studi Kasus: Cv. Xy),” Sebatik, Vol. 23, No. 1, pp. 277-284, doi: 10.46984/sebatik.v23i1.572.

[15] H. T. I. Driantami, Suprapto, and A. R. Perdanakusuma. 2018, "Analisis Risiko Teknologi Informasi Menggunakan ISO 31000 (Studi Kasus: Sistem Penjualan PT Matahari Department Store Cabang Malang Town Square),” J. Pengemb. Teknol. Inf. dan Ilmu Komput., Vol. 2, No. 11, pp. 4991-4998. 